\title{
Comparative Study for Estimation of Stature from Tibial Length in Egyptian and Bengali Adult Population
}

\author{
Naema Mahmoud Elhosary, Rabab Sayed El Kelany and Galal A. Eid ${ }^{1}$ \\ ${ }^{1}$ Department of Forensic Medicine and Clinical Toxicology, Faculty of Medicine, Tanta University, Tanta, Egypt.
}

\begin{abstract}
Forensic anthropologists employ in estimating stature from fragmented body parts or human skeletal remains. This study aimed at investigating the inter-racial difference between adult Egyptian and Bengali populations regarding the body stature and tibial length, developing regression equation formulae using the percutaneous length of tibia (PCTL) to estimate stature. Four groups of adult male and female Egyptian and Bengali subjects aged $>21$ were recruited randomly. Body height and PCTL were measured using the standard anthropometric technique. The means of the stature of the studied groups exhibited significant differences between all groups $(\mathrm{p}<0.001)$ except in Egyptian females versus Bengali male $(p=0.067)$. There was no significant difference within the same sex of both ethnic groups regarding the tibial length (Females $\mathrm{p}=0$.490) and (Males $\mathrm{p}=0.905)$. The measured parameters of males were significantly higher than the corresponding female values. The linear regression equations derived for male and female Egyptian were 94.080+2.145 x T $( \pm 3.57)$ and 76.617+2.375 x T $( \pm 3.89)$, respectively. Those for male and female Bengali were $92.500+1.870 \times \mathrm{T}( \pm 2.93)$ and $105.563+1.473 \times \mathrm{T}( \pm 2.39)$, respectively. It was concluded that the derived equations are flexible and retain realistic standard errors that can be used for stature estimation using the length of an intact mutilated leg. These equation formulae are Sex and ethnic specific. Thus, they should be endorsed in anthropological studies for stature estimation among the ethnic groups under this study.
\end{abstract}

\begin{tabular}{l|l} 
Keywords & Stature, Tibia, Bengali, Egyptian, Simple Linear Regression Equation.
\end{tabular}

\section{Introduction}

$\mathrm{F}$ orensic pathologist is responsible for establishment of the identity of the deceased during post-mortem examination which is a challenging task. As a result of the increased incidence of terrorism, the development of transportation facilities, aircraft crashes, and natural mass disasters; mutilated, dismembered and skeletonized materials become more common. In these cases, the forensic anthropologist is required to assist in partial identification by compiling a biological profile so; the possibility of individual identification can be narrowed (Saukko and Knight, 2016).

Along with age, sex, and race, stature is one of the most essential and useful anthropometric parameter, which determines the individual physical identity of human body or his/ her remains (Rastogi et al., 2009; Krishan et al., 2010). The standards for stature estimation are grounded on two main methods: the anatomical method, which necessitates the presence of a whole skeleton, or the mathematical method, that needs a complete long bone to employ multiplication factors or regression formulae. This mathematical method estimates the stature by deducing correlation between personal measurements of bones to living body height (Lundy 1985; Ahmed 2013).

Long bones of the lower extremity are considered the major contributor of stature. Following to femur, the measurement of tibial length helps in accurate estimation of stature more than any further long bone. This is because tibia can be reached simply and its length accounts for 22\% of the body height (Dikshit, 2002; Alka and Sharad, 2013). Likewise, percutaneous detection of tibial length in the living provides better degree of accuracy (Akhlaghi et al., 2011). Additionally, the role of tibia in anthropological research cannot be over-emphasized due to its resistance to disintegration and its ability to still retain its anatomical form long after death. (Iscan 1990; Williams et al., 1995; Krici and Ozan, 1999; Antonova et al., 2013). In contrast, Gruspier and Pollanen (2000) indicated that the tibia should be escaped, unless it is the only available bone and if the Trotter and Gleser formulae are used. They stated also, that the length of tibia must be started from the lateral condyle to the base, excluding the medial malleolus.

Several researchers studied this matter in different populations. Trotter and Gleser (1952, 1958) 
regression formula that assumed to estimate the stature from the long bones, have been used for many years. Later, it was recommended to formulate equations that are specifically derived for each sex and population to estimate stature. Genetic differences, isolation, differences in bio-cultural history, geographical climate and nutrition lie behind these population and sex specific regression equations (Dupertuis and Hadden, 1951; Trotter and Gleser, 1952; Lundy, 1983; Lundy and Feldesman, 1987).

Bengali populations are also known as Bengalis or Bengalees who are related to an Indo-Aryan ethnic group. They are inhabitants People' Republic of Bangladesh and Indian state of West Bengal located in the northwestern part of South Asia (Minahan, 2012), while the Egyptian are relevant to the Mediterranean Sea ethnic class which is a sub-race group of Caucasian race (Baum, 2006)

\section{Aim of the study}

This study aimed at investigating the inter-racial difference between adult Egyptian and Bengali population samples regarding the body stature and tibial length, developing regression equation formulae using the percutaneous length of tibia to estimate the body stature.

\section{Subjects and methods}

This is a cross sectional study conducted on two samples of populations; Egyptian and Bengali. Two hundreds subjects were recruited, 100 for each group (50 males and 50 females). The Egyptian subjects were volunteers that were invited for the study at the faculty of medicine, Tanta University, Tanta, Egypt. The Bengalis were collected randomly from the outpatient clinics of the General Hospital of Hail, KSA. All of the measurements were obtained after taking a signed written informed consent from all enrolled subjects following complete broad description of the study. Adults aged $\geq 18$ were selected. All subjects who suffered from congenital skeletal defects, pathologies, surgeries, chronic illnesses, or fractures that could affect the accuracy of measurements were excluded from this research. The Ethics Committee of Tanta Faculty of Medicine, Egypt approved the design of the study.

i. Anthropometric measurements were taken following Weiner and Lourie (1981) protocol:

1. Stature was measured with a stadiometer while, the participant was standing uprightly and recorded to the nearest 0.1 centimeter. It was taken as a distance from the utmost point on the head (vertex) to the heel. The head of each participant was kept in the Frankfort horizontal plane (eye ear plane) by supporting the participant's chin (World Health Organization, 2008) Living stature was measured in the morning to reduce the unwanted effects of diurnal stature variation (Floyd et al., 2017).
2. Percutaneous length of left tibia was measured by the spreading caliper in centimeters. The degree of the calipers arms separation was determined from their steel tape. The length of tibia represented as the distance between the tibiale; highest point on medial border of the medial condyle of the tibia to Spherion; the most distal point on the medial malleolus. The subject sat facing the examiner with the left ankle relaxing on the right knee, so that the medial side of the tibia exposed upwards. In this position, the tibiale point is easier to access.

ii. The stature of the enrolled subjects was estimated using the commonly developed regression equations which are designed by Pearson, (1899), Trotter and Gleser 1, 2 (1952, 1977), Patel et al., (1964) and Joshi et al., (1965) as shown in table (1)

\section{Statistical analysis}

The collected data were organized and statistically analyzed using SPSS software statistical computer package for windows version 20. The distribution of quantitative data was evaluated using Shapiro-Wilk test. Normally distributed data were expressed as mean and standard deviation. For comparison between the groups, one way ANOVA was used. If significant differences were present, post hoc test was performed (Tukey test). Data that were not normally distributed were expressed as median and mean rank and Kruskal-Wallis test was used for comparison between groups. Association between height and tibia length in the different studied groups was tested using Pearson's correlation.

Simple linear regression analysis was used to get regression equations for estimation of stature from tibia length. The equation used was: $\mathrm{Y}=\mathrm{a}+\mathrm{b}(\mathrm{x}) \pm$ S.E. Here, $Y$ is the dependent variable (the stature), a (the intercept) the point of crossing between the regression line and the $\mathrm{Y}$-axis, $\mathrm{b}$ the slope of the regression line (Regression coefficient), $\mathrm{x}$ the independent variable (tibial length) and S.E. is the standard error of estimate. Significance was adopted at $\mathrm{p}<0.05$ for interpretation of results of tests (Dawson and Trapp, 2001).

\section{Results}

Regarding the age range of the enrolled subjects in this study, there was no significant difference between all four groups P> 0.05 (Female Egyptians, male Egyptians, female Bengali and male Bengali). The median ages of the studied groups were 21.5, 21, 27, and 21 respectively.

The means of the stature of the studied groups exhibited significant differences between all groups $(\mathrm{p}<0.001)$ except Egyptian females versus Bengali male ( $\mathrm{p}=0.067)$. On the other hand, it was observed that there was no significant difference within the same sex of both ethnic groups regarding the tibial length. The $\mathrm{P}$ value of the tibial length in Egyptian female versus Bengal female was ( $p=0$.490) and in Egyptian male versus Bengal male 
was ( $p=0.905$ ), while significant difference was revealed between males and females in the same ethnic group $(\mathrm{P}<0.001)$ (Table. 2).

Table (3) demonstrated that the correlation coefficient (r) values between the tibial length and stature of the subjects of all studied groups were highly significant $(\mathrm{P}<0.001)$. They indicated strong positive correlation between them $(0.851,0.814)$ for Egyptian males and females, respectively and $(0.836,0.863)$ for Bengali males and females.

Table (4) presented the regression equation for each enrolled group that was used to estimate the living stature from the percutaneous length of tibia. All the created equations showed marked significance $(\mathrm{P}<0.001)$ in estimating the stature. The lowest Standard Error of the Estimate was observed with Bengali female group followed by the Bengali males. So, their developed equations were the most accurate inbetween the studied groups.

On calculating the stature of the enrolled subjects using the developed regression equations by this study together with the common equations designed by Pearson (1899), Tr. Gleser ${ }^{1,2}$ (1952, 1977), Patel et al., (1964) and Joshi et al., (1965), it was noticed that there were no significant differences between the actual and the predicted stature in all studied groups. The median actual stature of Egyptian males versus the median predicted by the Tr. Gleser ${ }^{1}$ equation $(S=78.62+2.52 \mathrm{~T})$ exhibited no significant difference. The actual stature of Bengali females showed insignificant differences with the Predicted stature by Tr. Gleser ${ }^{2}$ equation $(S=72.65+2.45 T)$. Furthermore, the predicted stature of Bengali males by Tr. Gleser ${ }^{2}$ and Joshi et al. equations $(\mathrm{S}=86.02+2.19 \mathrm{~T}$ and $\mathrm{S}=80.97+2.206 \mathrm{~T}$, respectively) revealed insignificant differences with their actual stature (Table 5).

On the other hand, the differences between the actual stature and that resulted after the application of the equation of Patel et al., (1964) were significantly high ranged from $(-15 \mathrm{~cm})$ in Bengali Male to $(+28 \mathrm{~cm})$ in Egyptian males.

Table (1): Different regression equations popularly used to calculate stature from tibial length

\begin{tabular}{|c|c|c|c|}
\hline Study & Male & Female & Sex Combined \\
\hline Pearson & $\mathrm{S}=78.664+3.378 \mathrm{~T}$ & $\mathrm{~S}=74.744+2.532 \mathrm{~T}$ & \\
\hline Tr. Gleser & & $\mathrm{S}=61.53+2.9 \mathrm{~T}$ & \\
\hline Tr. Gleser & $\mathrm{S}=78.62+2.52 \mathrm{~T}$ & $\mathrm{~S}=72.65+2.45 \mathrm{~T}$ & \\
\hline Patel et al. & $\mathrm{S}=86.02+2.19 \mathrm{~T}$ & & $\mathrm{~S}=65.51+2.203 \mathrm{~T}$ \\
\hline Joshi et al. & & & $\mathrm{S}=80.97+2.206 \mathrm{~T}$ \\
\hline
\end{tabular}

${ }^{1}$; study of white Americans, 1952 and 1977; ${ }^{2}$; study of Black Negroes, 1952 and 1977, S; Stature, T; Tibial length (Anirban et al., 2013)

Table (2): Statistical analysis (Post hoc test) for comparison of age, stature and tibial length between both sexes of Egyptian and Bengali population

\begin{tabular}{|c|c|c|c|c|c|c|c|}
\hline & \multicolumn{4}{|c|}{ Groups } & \multirow{2}{*}{\multicolumn{2}{|c|}{ Tests of significance }} \\
\hline & & \multicolumn{2}{|l|}{ Egyptians } & \multicolumn{2}{|l|}{ Bengali } & & \\
\hline & & Female & Male & Female & Male & $\begin{array}{l}\text { Test } \\
\text { statistic }\end{array}$ & $\mathrm{p}$ \\
\hline \multirow{3}{*}{$\begin{array}{l}\text { Age } \\
\text { (years) }\end{array}$} & Range & $18.0-42.0$ & $18.0-45.0$ & $18.0-40.0$ & $19.0-31.0$ & \multirow[t]{3}{*}{$\mathrm{Z}_{\mathrm{kw}}=4.49$} & \multirow[t]{3}{*}{0.213} \\
\hline & Median & 21.50 & 21.0 & 27.0 & 21.0 & & \\
\hline & Mean rank & 2.00 & 1.00 & 4.00 & 3.00 & & \\
\hline \multirow{2}{*}{$\begin{array}{l}\text { Stature } \\
(\mathrm{cm})\end{array}$} & Range & $145.0-175.0$ & $162.0-189.0$ & $147.0-166.0$ & $154.0-170.0$ & \multirow{2}{*}{$\begin{array}{l}\mathrm{F}= \\
98.93\end{array}$} & \multirow[t]{2}{*}{$<0.001^{*}$} \\
\hline & Mean \pm SD & $159.56 \pm 6.63$ & $175.06 \pm 6.73$ & $155.97 \pm 4.68$ & $162.48 \pm 5.3$ & & \\
\hline
\end{tabular}

Post hoc test (Tukey test) revealed significant differences between all groups except Egyptian females versus Bengal males ( $\mathrm{p}=0.067)$

\begin{tabular}{|l|l|l|l|l|l|l|l|l}
\hline $\begin{array}{l}\text { Tibial } \\
\text { length } \\
(\mathrm{cm})\end{array}$ & Range & $32.0-41.0$ & $33.0-45.0$ & $30.0-38.75$ & $32.50-40.0$ & $\mathrm{~F}=$ & $<0.001^{*}$ \\
\cline { 1 - 6 } & Mean \pm SD & $34.93 \pm 2.27$ & $37.76 \pm 2.67$ & $34.22 \pm 2.74$ & $37.42 \pm 2.37$ & 24.67 & \\
\hline
\end{tabular}

Post hoc test (Tukey test) revealed significant differences between all groups except Egyptian female versus Bengali female $(\mathrm{p}=0.490)$ and Egyptian male versus Bengali male $(\mathrm{p}=0.905)$

*significant at $p<0.05, Z_{k w:}$ Kruskal -Wallis test, F; one way ANOVA, SD; Standard Deviation, cm: centimeter 
Table (3): Pearson's correlation between tibial length and Stature in both Egyptian and Bengali population

\begin{tabular}{|c|c|c|c|c|c|}
\hline \multirow[t]{3}{*}{ Races } & & \multicolumn{4}{|c|}{ Stature $(\mathrm{cm})$} \\
\hline & & \multicolumn{2}{|c|}{ Males } & \multicolumn{2}{|c|}{ Females } \\
\hline & & $\mathrm{r}$ & $\mathrm{P}$ value & $\mathrm{r}$ & $\mathrm{P}$ value \\
\hline Egyptians & Tibial length $(\mathrm{cm})$ & 0.851 & $\begin{array}{l}.001 * \\
\end{array}$ & 0.814 & $<.001^{*}$ \\
\hline Bengali & Tibial length (cm) & 0.836 & $<.001 *$ & 0.863 & $<.001^{*}$ \\
\hline
\end{tabular}

*significant at $p<.05$, $r$ : Pearson's correlation coefficient.

Table (4): Simple linear regression analysis and regression equations for stature estimation in both Egyptian and Bengali Populations

\begin{tabular}{|c|c|c|c|c|c|}
\hline Race & Sex & Regression equation & Accuracy $\left(\mathrm{R}^{2}\right)$ & P value & Std. Error of the Estimate \\
\hline Egyptians & Males & $\mathrm{S}(\mathrm{cm})=94.080+2.145 \times \mathrm{xT}(\mathrm{cm})$ & $72.4 \%$ & $<.001^{*}$ & \pm 3.57 \\
\cline { 2 - 6 } & Females & $\mathrm{S}(\mathrm{cm})=76.617+2.375 \times \mathrm{T}(\mathrm{cm})$ & $66.3 \%$ & $<.001^{*}$ & \pm 3.89 \\
\hline \multirow{2}{*}{ Bengali } & Males & $\mathrm{S}(\mathrm{cm})=92.500+1.870 \times \mathrm{T}(\mathrm{cm})$ & $69.9 \%$ & $<.001^{*}$ & \pm 2.93 \\
\cline { 2 - 6 } & Females & $\mathrm{S}(\mathrm{cm})=105.563+1.473 \mathrm{x} \mathrm{T}(\mathrm{cm})$ & $74.4 \%$ & $<.001^{*}$ & \pm 2.39 \\
\hline
\end{tabular}

S; Stature, T; Tibial length; *significant at $p<0.05, R^{2}$; Coefficient of determination, Std; Standard, cm; centimeter.

Table (5): Statistical analysis (Friedman Test) to compare between the actual stature in this study and the predicted stature using our regression equation and other common equations

\begin{tabular}{|c|c|c|c|c|c|}
\hline & \multicolumn{4}{|c|}{ Groups } \\
\hline & & $\begin{array}{c}\text { Egyptian } \\
\text { Females }\end{array}$ & $\begin{array}{c}\text { Egyptian } \\
\text { Males }\end{array}$ & $\begin{array}{c}\text { Bengali } \\
\text { Females }\end{array}$ & $\begin{array}{c}\text { Bengali } \\
\text { Males }\end{array}$ \\
\hline & & Median & Median & Median & Median \\
\hline \multicolumn{2}{|l|}{ Actual stature } & 158.50 & 175.00 & 156.00 & 163.00 \\
\hline \multicolumn{2}{|c|}{ Predicted stature by our regression equation } & $157.37^{\#}$ & $173.45^{\#}$ & $154.17^{\#}$ & $162.63^{\#}$ \\
\hline \multirow{2}{*}{\multicolumn{2}{|c|}{ Predicted stature by Pearson (1899) }} & 160.83 & 203.65 & 158.30 & 205.34 \\
\hline & & $\$+3.46$ & $\$+30.2$ & $\$+4.13$ & $\$+42.71$ \\
\hline \multirow{2}{*}{\multicolumn{2}{|c|}{ Predicted stature by Tr. Gleser ${ }^{1}$}} & 160.13 & $171.86^{\#}$ & 157.23 & 173.12 \\
\hline & & $\$+2.76$ & $\$+1.59$ & $\$+3.06$ & $\$+10.49$ \\
\hline \multirow{2}{*}{\multicolumn{2}{|c|}{ Predicted stature by Tr. Gleser ${ }^{2}$}} & 155.95 & 167.05 & $153.50^{\#}$ & $168.15^{\#}$ \\
\hline & & $\$-1.42$ & $\$-6.4$ & $\$-0.67$ & $\$+5.52$ \\
\hline \multirow{2}{*}{\multicolumn{2}{|c|}{ Predicted stature by Patel et al. }} & 140.41 & 147.02 & 138.21 & 148.12 \\
\hline & & $\$-16.96$ & $\$-26.43$ & $\$-15.96$ & \$-14.51 \\
\hline \multirow{2}{*}{\multicolumn{2}{|c|}{ Predicted stature by Joshi et al. }} & 155.97 & 162.59 & 153.77 & $163.70^{\#}$ \\
\hline & & $\$-1.4$ & $\$-10.86$ & $\$-0.4$ & $\$+1.07$ \\
\hline \multirow{2}{*}{ Friedman Tes } & $\mathrm{z}$ & 231.81 & 261.53 & 202.92 & 271.34 \\
\hline & $\mathrm{p}$ & $<.001 *$ & $<.001 *$ & $<.001^{*}$ & $<.001^{*}$ \\
\hline
\end{tabular}

(*); significant at $p<0.05$, superscript $\left({ }^{\$}\right)$; significant difference from the median of Present Study, superscript $\left({ }^{\sharp}\right)$; no significant differences with the median actual stature, Z; Friedman Test

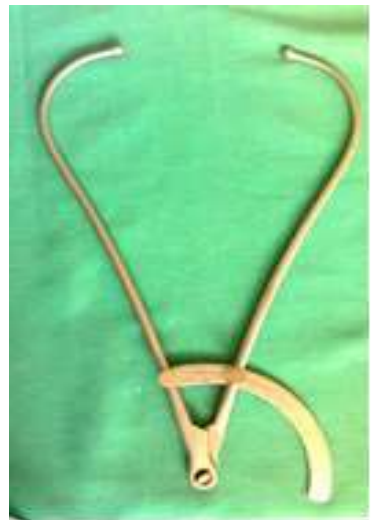

Fig (1): Manual spreading caliper

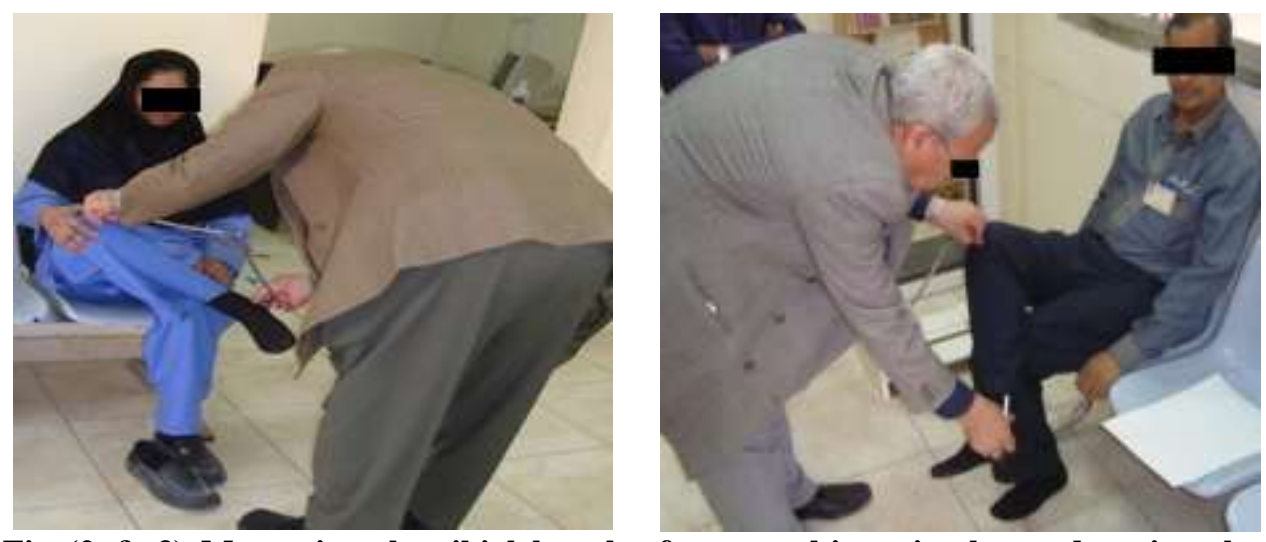

Fig $(2 \& 3)$ Measuring the tibial length of some subjects in the study using the spreading caliper 


\section{Discussion}

The estimation of stature is essential in forensic anthropology where the rising frequency of mass disasters causes bony fragments and dismembered human remains. The external examination done before autopsy include measurements that help the regression equations to be used in estimating living stature (Christensen et al., 2015).

As postulated the regression equations for stature estimation are population and sex specific, this necessitates the researches to be done on a regional foundation. So, this study was undergone to derive equations for estimation of stature of Egyptian and Bengali male and female populations.

In (1952) Trotter and Gleser concluded that increase in stature after 18 years is insignificant and there is no statistical significant alteration after age 18. For that reason the current study was done on persons aged $\geq 18$ years. To remove the impact of the epiphyseal growth element in regression equations construction, it is preferred to select the individual aged more than 21 . The studies of El-Meligy et al., (2006) \& Alka and Sharad (2013) were conducted on both male and female Egyptian and Indian students aged from of 19-21 years and 18- 24 years, respectively.

In the present work, the means of the measured stature and tibial length showed significant increase in males than in females of the same age and population group. This can be clarified based on the fact of epiphyseal union occurs earlier in female than male. So, boys have a chance for bony growth of about two years than girls which was conveyed as surpass of the somatometric measurements of the adult male (France, 1998).

In this current work, it was noted that both Egyptian males and females' statures were significantly higher than their corresponding Bengali groups, but there was no significant statistical difference between Egyptian females and Bengali males. This can be explained by that the stature is influenced by several factors other than sex and race (Lundy, 1983). On the other hand, the tibial length exhibited non-significant relation within the same sex of the two studied populations.

These observations indicated that the role of tibial length was not marked in causing stature variation within the same sex of the two studied population. Trotter and Gleser (1958) supported this assumption that comparison of bone lengths showed no difference in limb length but significant stature differences between the victims of World War II and Korean War. The increased stature in Korean group is attributed to later growth in the spinal region (secular trend), not due to bones of the leg.

The present study showed that stature was significantly and positively correlated with the tibial length ( $r \geq 0.814)$. These findings were consistent with previous studies that were undertaken by Dayal et al. (2008) and Brits et al. (2017) on South African Whites males and South African females, which were 0.88 and
0.875 , respectively. The value of ( $r$ ) in this study was higher than study of Kaore et al. (2012) that was conducted on Navodaya group of institutions and RIMS, Raichur, India as (r) values were 0.797 for males and 0.694 for females.

The study done by El-Meligy et al., (2006) in Assiut region in Egypt showed that the (r) values were 0.75 for males, and 0.48 for females, while another study done by Trivedi et al. (2014) on people of Gwalior region, India revealed that the $(r)$ values were 0.4342 for males and 0.6014 for females.

On the other hand, (r) values of this present study was lower than the studies of Dayal et al. (2008), Anirban et al. (2013) and Brits et al. (2017) that done on south African whites females, Eastern Indians, and black south African males, respectively. This variability may be caused by group specific differences in the mean height and mean tibial length together with unlike age ranges.

In the present study, the SEE of the linear regression equations ranged from 2.39 to $3.57 \mathrm{~cm}$. SEE of the present study was consistent with Mohanty (1998) and Brits et al. (2017) but was lower than that reported by El-Meligy et al. (2006) (8.24, 6.51 and 8.10 for male, female and both sexes). In contrast, they were higher than Kaore et al. (2012) and Anirban et al. (2013) (less than $1 \mathrm{~cm}$ in both males and females). Estimate of stature was derived from a linear regression model when a single measurement is available from the extremities. The reliability of regression equations in stature estimation is discovered by the standard error of estimate (SEE) which expects the deviation of predicted stature from actual stature and is considered as a degree of the equations correctness.

In this study, when the popular postulated regression equations for estimation of the stature from the tibial length were applied on the participant groups, there were significant differences except for some groups as mentioned in table 5. The difference between the estimated stature of Egyptian and Bengali males by application of the present regression equation and that of Pearson was much more (overestimation of $30.2 \mathrm{~cm}$ and $42.71 \mathrm{~cm}$ respectively). However for Egyptian and Bengali Females, an overestimation of $3.46 \mathrm{~cm}$ and 4.13 $\mathrm{cm}$ were obtained. Thus, while the equation of Pearson for females was closely followed the present regression estimations than for males yielded a wider difference.

Following calculating the stature by using the Tr. Gleser's equations, it was observed that the equation of white Americans gave measures slightly greater than the current study for all groups except for Egyptian males the difference was more evident $(+2.76,+1.59$, +3.06, +10.49 , respectively). However, application of the second equation was reliable for both Egyptian and Bengali female groups as the gap was acceptable (-1.42, $0.67)$, respectively. But, it presented under- estimation of 
stature's Egyptian Males $(-6.4 \mathrm{~cm})$ and over-estimation in Bengali male group $(+5.52 \mathrm{~cm})$.

The common equation of Patel et al. underestimated the stature of all studied groups, so it was not at all feasible to be applied for estimation of stature on these groups of population. Finally, Joshi et al. common equation also undervalued the stature of the Egyptian males by $10.86 \mathrm{~cm}$ less than the current study.

\section{Conclusion}

The derived equations are flexible and retain realistic standard errors that can comprise such minimal changes. The introduced formulae are ethnic group and Sex specific that cannot be applied to other ethnic group or population. Thus, the equations of this study should endorsed in anthropological and forensic pathological studies for estimation of stature among the ethnic groups (Egyptian and Bengali) within study.

\section{Recommendation}

Further studies should be encouraged but on a large scale all over Egypt to develop linear regression equations to estimate the stature specific for both Egyptian sexes. Then, these equations should be validated to become usable in cases of mass disasters. As the sample used in the current study was insufficient.

\section{Acknowledgments}

The authors are thankful to all the Egyptian and Bengali participants of this study, and all members of the Forensic medicine and Clinical Toxicology Department, Faculty of Medicine, Tanta University.

\section{References}

Ahmed AA (2013): Estimation of stature from the upper limb measurements of Sudanese adults. Forensic Sci. Int. 228(1-3):178.e1-178.e7.

Akhlaghi M, Sheikhazadi A, Khosravi N et al., (2011): The value of the anthropometric parameters of the tibia in the forensic identification of the Iranian population over the age of 20. J. Forensic Leg. Med. 18: 257-263.

Alka DS and Sharad DA (2013): Estimation of stature from percutaneous measurement of tibia in living. Medico-Legal Update. 13(2): 5-7.

Anirban D, Arindam B and Prithviraj K (2013): Estimation of Stature of Eastern Indians from Measurements of Tibial Length. Anatom. Physiol. 3(1) http://dx.doi.org/10.4172/2161-0940.1000115

Antonova E, Le TK, Burge R et al., (2013): Tibia shaft fractures: Costly burden of nonunions. BMC Musculoskelet. Disord. 14(42):1-10.

Baum B (2006): Passage into "our ordinary forms of expression": "The Caucasian Race," ca.17951850. In: The Rise and Fall of The Caucasian Race: A Political History of Racial Identity, Baum B (ed), New York University Press, New York and London. pp: 95-117.

Brits DM, Bidmos MA and Manger PR (2017): Stature estimation from the femur and tibia in Black South African sub-adults, Forensic Sci. Int. 270: 277.e1277.e10
Christensen AM, Passalacqua NV, Schmunk GA et al., (2015): The value and availability of forensic anthropological consultation in medicolegal death investigations. Forensic Sci Med Pathol. 11:438441.

Dawson B and Trapp RG (2001): Basic and clinical biostatistics. In: Lange Medical Book, Dawson B and Trapp RG (eds), $3^{\text {rd }}$ ed., McGrow Hill Medical Publishing Division, New York. pp. 161-218.

Dayal MR, Steyn M and Kuykendall Kl (2008): Stature estimation from bones of South African whites. S. Afr. J. Sci. 104: 124-128.

Dikshit PC (2002): HWV Cox Medical jurisprudence and Toxicology. $7^{\text {th }}$ ed., LexisNexis Butterworths, India.

Dupertuis CW and Hadden J (1951): On the reconstruction of stature from long bones. Am. J. Phys. Anthropol. 9: 15-54.

El-Meligy MM, Abdel-Hady RH, Abdel-Maaboud RM et al., (2006): Estimation of human body built in Egyptians. Forensic Sci Int. 159(1): 27-31.

Floyd B, Jayasinghe L and Dey C (2017): Factors influencing diurnal variation in height among adults. HOMO. 68(3): 236-241.

France DL (1998): Observational and metric analysis of sex in the skeleton. In: Forensic Osteology: Advances in the Identification of Human Remains, Reiche KJ (ed), $2^{\text {nd }}$ ed., Charles, C. Thomas, Springfield. pp. 163-186.

Gruspier K and Pollanen M (2000): Limbs found in water: investigation using anthropological analysis and the diatom. Forensic Sci. Int. 112: 1-9.

İşcan MY (1990): A comparison of techniques on the determination of race, sex and stature from the terry and hamman-todd collections. In: Skeletal Attribution of Race: Methods for Forensic Anthropology, Gill GW and Rhine JS (eds). University of New Mexico, Maxwell Museum of Anthropology Papers, Albuquerque. 4: 73-82.

Joshi NB, Patel MP and Amin MG (1965): Use of tibia and ulna in the estimation of total body height. Indian J. Med. Res. 53: 831-834.

Kaore A, Kaore BP, Kamdi A et al., (2012): Stature Estimation From Tibial Length. NJIRM. 3(2): 5156.

Krici Y and Ozan H (1999): Determination of sex from the tibia of adult Turkish cadavers. Kaibogaku Zasshi. Journal of Anatomy. 45: 537-543.

Krishan K, Kanchan T and DiMaggio JA (2010): A study of limb asymmetry and its effect on estimation of stature in forensic case work. Forensic Sci. Int. 200 (1-3): 181.e1-181.e5.

Lundy JK (1983): Regression equations for estimating living stature from long limb bones in the South African Negro. S. Afr. J. Sci. 79: 337-338.

Lundy JK (1985): The mathematical versus anatomical methods of stature estimate from long bones. Am. J. Forensic Med. Pathol. 6:73-76. 
Lundy JK and Feldesman MR (1987): Revised equations for estimating living stature from long bones of the South African Negro. S. Afr. J. Sci. 83: 54-55.

Minahan JB (2012): Ethnic Groups of South Asia and the Pacific: An Encyclopedia. ABC CLIO, Santa Barbara, California. pp: 32-35.

Mohanty NK (1998): Prediction of height from percutaneous tibial length amongst Oriya population. Forensic Sci. Int. 98: 137 -141.

Patel MP, Joshi NB and Dongre AV (1964): Regression equation of height on tibial length. Indian J. Med. Res. 52: 531-534.

Pearson K (1899): IV. Mathematical contribution to the theory of evolution on the reconstruction of the stature of prehistoric races. Philos. Trans. R. Soc. series A. 192:169 -241.

Rastogi P, Kanchan T, Menezes RG et al., (2009): Middle finger length da predictor of stature in Indian population. Med. Sci Law. 49:123e6.

Saukko P and Knight BCBE (2016): The establishment of identity of human remains. In: Knight's Forensic Pathology, Saukko P and Knight BCBE (eds), $4^{\text {th }}$ ed., CRC press. Boca Raton, London, Ch3.pp. 95-132.

Trivedi A, Saxena S, Morya R et al., (2014): Stature Estimation Using Per-Cutaneous Tibial Length in
People of Gwalior Region. IOSR-JDMS. 13(5): 65-70.

Trotter M and Gleser GC (1952): Estimation of stature from long bones of American Whites and Negroes. Am. J. Phys. Anthropol. 10: 463-514.

Trotter M and Gleser GC (1958): A re-evaluation of estimation of stature based on measurements of stature taken during life and of long bones after death. Am. J. Phys. Anthropol.16: 79-123.

Trotter M and Gleser GC (1977): Corrigenda to "estimation of stature from long limb bones of American Whites and Negroes, (1952)" Am. J. Phys. Anthropol. 47(2): 355-356.

Weiner JS and Lourie JA (1981): Practical Human Biology. Academic Press, London; New York.

Williams PL, Warwick R, Dyson M et al., (1995): Skeletal System. In: Gray's Anatomy, $37^{\text {th }}$ ed., Churchill Living Stone, London. pp. 601-612.

World Health Organization (2008): WHO Child Growth Standards: Training Course on Child Growth Assessment. B: Measuring a Child's Growth World Health Organization, Switzerland Available at

http://www.who.int/childgrowth/training/module_ h_directors_guide.pdf, (accessed 14.03.15).

\section{الملخص العربى \\ دراسة مقارنة لتقدير طول القامة باستخدام طول عظم الساق في كل من السكان البالغين المصريين والبنغاليين}

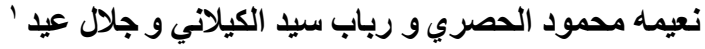

$$
\begin{aligned}
& \text { يشتمل عمل علماء الانثروبولوجيا الشرعيين على تقدير طول القامة من أجزاء جسم الانسان المفتتة أو بقايا هيكله العظمى. تهدف هذه هذه الدراسة الي } \\
& \text { التحقيق في الفرق العنصري بين السكان البالغة المصرية والبنغالية من حيث طول القامة، طول عظم الساق، ومعادلة الانحدار الخطية المشتقة من طول عظم الساق } \\
& \text { عن عايق الجلد لتقدير طول القامة. تم تشكيل أربع مجموعات عشوائية من البالغين الذكور والإناث المصرية والبنغالية الذين تتراوح أعمارهم فوق إعاما. } \\
& \text { تم قياس ارتفاع الجسم وطول الساق عن طريق الجلد باستخدام تقنيه قياسية معيارية. ووجد اختلافات إحصائية كبيرة في متوسط طول القامة بين جميع الفئات المدروسة } \\
& \text { (p) 001) فيما عدا الإناث المصرية مقابل الذكور البنغالية(p=0.067) وبالنسبة لطول عظم الساق كان لا يوجد هناك اختلاف ذو قيمة إحصائية داخل } \\
& \text { نفس الجنس من كلا العرقيين (الاناث p=0.490 والذكور p=0.905). كانت المعلمات المقاسة (طول القامة وطول عظم الساق) للذكور أعلى بكثير من قيم }
\end{aligned}
$$

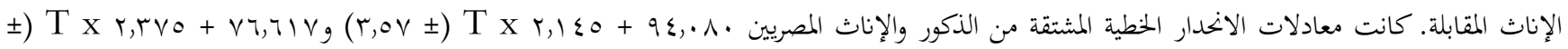

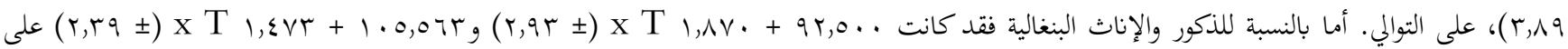

